\title{
COLLAGEN EXTRACTION FROM BONE OF Lutjanus sp. AND TOXICITY
} ASSAY

\author{
Leliani $^{1}$, Hasnah Natsir ${ }^{2,3^{*}}$, Seniwati Dali ${ }^{2,3}$, Sartika $^{1}$ \\ ${ }^{1}$ Graduate Student, Magister Program of Chemistry, Mathematics and Natural Science Faculty, \\ Hasanuddin University, Makassar 90245, Indonesia. \\ ${ }^{2}$ Department of Chemistry, Mathematics and Natural Science Faculty, Hasanuddin University, 90245, \\ Indonesia. \\ ${ }^{3}$ Laboratory of Biochemistry, Mathematics and Natural Science Faculty, Hasanuddin University, \\ Makassar 90245, Indonesia. \\ *Corresponding author. E-mail : hasnahnatsir@gmail.com
}

\begin{abstract}
Abstrak. Indonesia adalah negara maritim dengan potensi sumber daya perikanan. Namun, pemanfaatan hanya berkisar pada daging, sementara bagian lain tidak digunakan secara optimal, terkhusus tulang ikan yang berpotensial menghasilkan kolagen, sehingga hal ini perlu untuk dikembangkan. Tujuan dari penelitian ini adalah mengekstraksi kolagen dari Lutjanus sp. dan menentukan apakah terdapat aktivitas antikanker. Kolagen diektraksi dengan menggunakan metode hydroextraction dan identifikasi dengan FTIR. Penaringan awal kegiatan antikanker dilakukan dengan menggunakan metode Brine Shrimp Lethality Test (BSLT) untuk uji toksisitas. Hasil penelitian menunjukkan bahwa kolagen yang dihasilkan berkisar $4,535 \%$ dengan konsentrasi protein berkisar $8.815 \mathrm{mg} / \mathrm{mL}$. Kolagen yang diidentifikasi memiliki spectrum Amida A, B, I, II, and III pada serapan 3421,72; 2926,01; 1651,07; 1541,12; 1240,23 $\mathrm{cm}^{-1}$. Tes Toksisitas ditunjukkan dalam nilai $\mathrm{LC}_{50}$ sebesar $8,760 \mu \mathrm{g} / \mathrm{mL}$. Kolagen dari tulang Lutjanus $s p$. dapat digunakan sebagai agen antikanker alami.
\end{abstract}

Kata Kunci : Kolagen, Lutjanus sp., Tulang, Antikanker, Hidroextraction, BSLT.

Abstract. Indonesia is a maritime country with potential fisheries resources. However, utilization only revolves around the meat, while other parts have not been used optimally, especially fish bones which have the potential to produce collagen, so it needs to be developed. The aims of this study ware extracted collagen from bone of Lutjanus sp. and determine its Anticancer activity. The collagen was extracted by using hydroextraction method and identification by FTIR. The initial screening anticancer activity was done by using Brine Shrimp Lethality Test (BSLT) method for toxicity assay. The results showed that the yield of collagen was $4.535 \%$ with protein concentration was $8,815 \mathrm{mg} / \mathrm{mL}$. Identified collagen from spectrum of amide A, B, I, II, and III at $3421.72 ; 2926.01 ; 1651.07 ; 1541.12 ; 1240.23 \mathrm{~cm}^{-1}$. The toxicity test was shown in $\mathrm{LC}_{50}$ values of $8.760 \mu \mathrm{g} / \mathrm{mL}$. The collagen from Lutjanus sp. bone can be used as natural anticancer agent.

Keywords : Collagen, Lutjanus sp., Bone, Anticancer, Hidroextraction, BSLT. 


\section{INTRODUCTION}

Collagen is a fibrous protein with three polypeptide chains that form a triple helix. collagen has characteristics, composed of repetitive tripeptides (GlyXaa-Yaa) which are stabilized by hydrogen and intermolecular bonds (Gelse \& Aigner, 2003; Duarte et al, 2016). Xaa and Yaa can be occupied by other amino acids, including proline (28\%) hydroxyproline (38\%) and generally $10.5 \%$ are arranged in the ProHypGly sequence (Shoulders \& Raines, 2009). Collagen is found in vertebrate animals and accounts for $30 \%$ of the total protein contained in the body. Collagen is an organic structure found in connective tissue such as bones, tendons, blood vessels, skin, teeth and muscles (Silva \& Penna, 2012).

Collagen extracted from marine animals is one of the alternative sources of collagen replacing collagen from land animals such as cattle, goats, chickens and pigs which are feared for issues of illness or prohibition in some religions. Marine animal collagen has several advantages including free of zoonoses such as Bovine Spongiform Encephalopathy (BSE), Transmissible Spongiform Encephalopathy (TSE) and Foot and Mouth Disease (FMD), easily absorbed, accepted by many religions, mild regulatory problems and quality control, low inflammatory response, and in accordance with the metabolic system (Silvipriya et al, 2015)

At present, collagen has various applications in various sectors, namely foods, cosmetics and the pharmaceutical. In biomedical application, collagen is used as shield, Sponges for burns,
Nanoparticles for gene delivery, matrix for protein and drug delivery (Lee et al, 2001). This is because of the presence of the functional groups, amino and carboxylic acid, which helps in its modification that suits for various end uses (Muthukumar, 2018) . In addition, the study found that collagen had an inhibitory effect on the growth of human cancer cells (Han, 2011).

Indonesia has potential fisheries resources, one of which is red snapper. However, utilization only revolves around meat, while other parts have not been used optimally, especially fish bones that have the potential to produce collagen. However, little information about collagen from red snapper (Lutjanus sp.) Has been reported. The purpose of this study was to produce collagen with anticancer activity of red snapper bones (Lutjanus sp.).

\section{MATERIAL AND METHODS Instruments}

The instrument used include analytical scales, UV-Vis Spectrophotometer Shimadzu UV-2600, Magnetic Stirrer, drop pipette, erlenmeyer, beaker, measuring flask, stirring bar, spray bottle.

\section{Material}

Bones of Red snapper (Lutjanus sp.), $\mathrm{NaOH}, \mathrm{CH}_{3} \mathrm{COOH}, \mathrm{KBr}$, and BSA.

\section{Methods}

\section{Collagen Extraction}

Collagen extracted from bone of Lutjanus sp. used by modification of Baehaki et al (2015) method. Pretreatment, the bones, which has been cut into small pieces and washed, were 
treated with $0.1 \mathrm{M} \mathrm{NaOH}$ at a ratio of $1: 10(\mathrm{w} / \mathrm{v})$ for $6 \mathrm{~h}$, and the solution was changed every $2 \mathrm{~h}$ and finally washed with the aquadest. Hydrolysis with $1.5 \%$ $\mathrm{CH}_{3} \mathrm{COOH}$ at a ratio of $1: 2(\mathrm{w} / \mathrm{v})$ for 24 $\mathrm{h}$, then washed with the aquadest. Collagen was Extracted by using aquadest at a ratio of $2: 1(\mathrm{w} / \mathrm{v})$ for $3 \mathrm{~h}$ at $45{ }^{\circ} \mathrm{C}$. Collagen solution was freeze dryed.

\section{Infrared Spectroscopy}

Fourrier Transform Infra Red spectra were obtained from collagen in approximately potassium bromide $(\mathrm{KBr})$ on a Shimmadzu FT-IR spectrometer in the range of $300-4000 \mathrm{~cm}^{-1}$.

\section{Toxicity Assay}

Toxicity assay by using Brine Shrimp Lethality Test (BSLT) and shown the $\mathrm{LC}_{50}$ value of collagen.

\section{RESULT AND DISCUSSION}

\section{Extraction of Bone Collagen}

The extraction collagen from Lutjanus sp. bone consists of three steps, these are pretreatment using $\mathrm{NaOH}$, hydrolysis using acetic acid and extraction using aquadest. The pretreatment aims to eliminate noncollagenous proteins (Silva et al, 2014) and impurity. it can be seen from the colour which turns white in the material. The hydrolysis aims to break the crosslinked collagen which presents in the connective tissue of animals before extraction. In this cased, the material swells and cleavages the non-covalent inter and intra-molecular bonds (Schmidt, 2016).

The yields of collagen extracted from Lutjanus $s p$ found at $4.535 \%$. This value was observed higher than the yield of collagen from Tilapia (Oreochromis mossambicus) Bone (3.5\%) (Liu \& Huang, 2016) and bigeye snapper (Priacanthus tayenus) bone (1.59\%) by ASC extraction method (Kittiphattanabawon, 2005), but lower than bone collagen of yellow sea bream (Dentex tumifrons) (40.1\%) (Nagai \& Suzuki, 2000) and Pangasius catfish (Pangasius pangasius) by hydroextraction method (12.86\%) (Baehaki, 2016). Apparently the collagen of Lutjanus sp. bones is relatively small. This is thought to be a strong hydrogen bond in the collagen structure so that the break up during extraction is difficult. Besides that, some collagen is lost during neutralization. The difference in yields of collagen might be caused by the difference in extraction methods and the fish species. Furthermore, the protein content obtained is $8.815 \mathrm{mg} / \mathrm{mL}$.

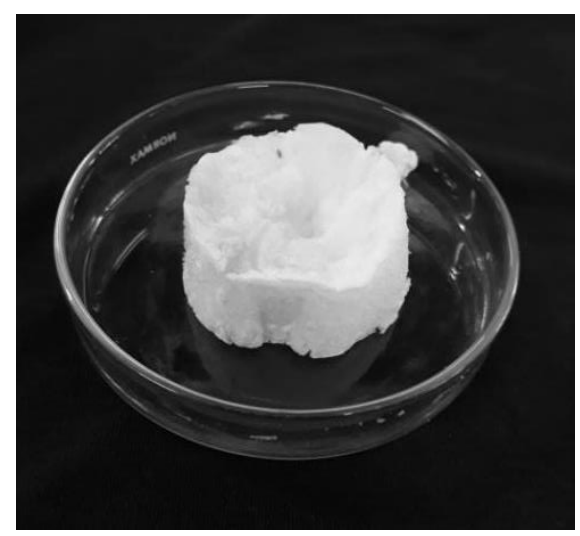

Figure 1. Collagen from Lutjanus sp. Bone

\section{Infrared Spectroscopic Analysis}

FTIR spectra of extracted collagen is shown in Fig. 2 and table 1. The absorption bands of amides I, II, III, $\mathrm{A}$, and $\mathrm{B}$ were observed. The amide $\mathrm{A}$ 
band was observed in $3421.72 \mathrm{~cm}^{-1}$. This band is associated with $\mathrm{N}-\mathrm{H}$ stretching vibration in the range of $3400-3440 \mathrm{~cm}^{-1}$ (Veeruraj et al, 2013). Different from several studies (Liu \& Huang, 2016; Tziveleka et al, 2017), where amide A is in the range of $3300 \mathrm{~cm}^{-1}$. This shift is because the $\mathrm{NH}$ group binds to hydrogen bonds. The amide $\mathrm{B}$ band, related to the asymmetrical stretch of $\mathrm{CH}_{2}$ was observed at $2926.01 \mathrm{~cm}^{-1}$. The amide I band, resonating in the range of 1600$1700 \mathrm{~cm}^{-1}$, was found in $1651.07 \mathrm{~cm}^{-1}$. This band mainly associated with the $\mathrm{C}=\mathrm{O}$ stretching vibration which the most intense band in proteins and sensitive marker of the secondary structure of the protein (Veeruraj et al, 2013; Tziveleka et al, 2017). The amide II band, resonating in the range of $1480-1575 \mathrm{~cm}^{-}$ ${ }^{1}$, associated with the $\mathrm{N}-\mathrm{H}$ bending vibration coupled with the $\mathrm{C}-\mathrm{N}$ stretching vibration, was found at $1541.12 \mathrm{~cm}^{-1}$. The finally, the amide III band, resonating in the range of 1229$1301 \mathrm{~cm}^{-1}$ which attributed to the C-N stretching vibration in combination with the $\mathrm{N}-\mathrm{H}$ deformation, was observed at $1240.23 \mathrm{~cm}^{-1}$. The amide III band can identicate the triple helix in extracted collagen. The ratio between amide III and the band at approximately $1450 \mathrm{~cm}^{-}$ 1 which approaches one indicates the presence of a triple helix (0.85) (Tziveleka et al, 2017).

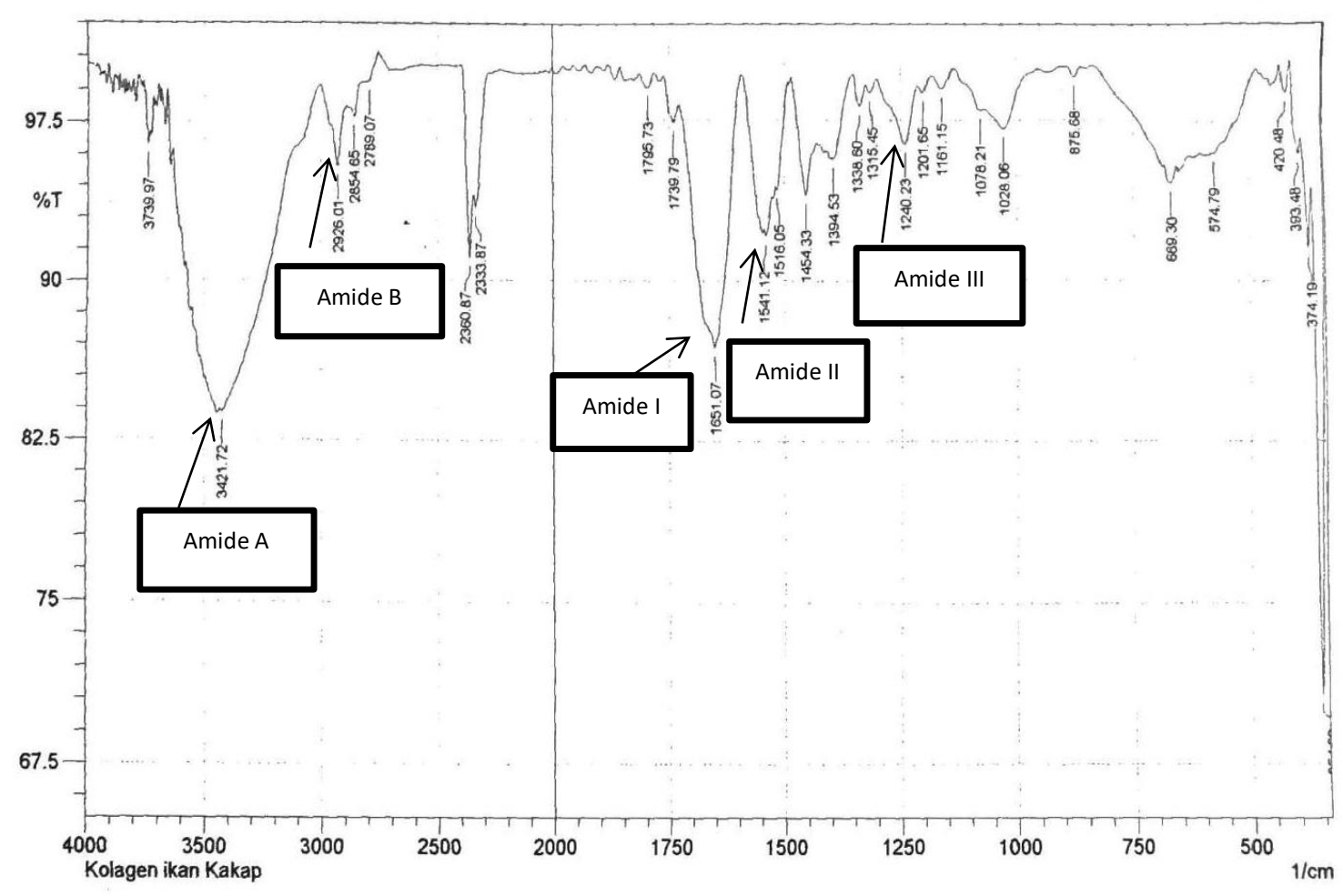

Figure 2. IR Spectra of collagen from Lutjanus sp. Bone 
Table 1. IR Spectra Peak Position and assignments for collagen from Lutjanus sp. Bone

\begin{tabular}{lccc}
\hline Region & $\begin{array}{c}\text { Peak } \\
\text { Wavenumber }\left(\mathbf{c m}^{-1}\right)\end{array}$ & $\begin{array}{c}\text { Absorption } \\
\text { Region }\end{array}$ & $\begin{array}{c}\text { Region Peak Assignment } \\
\text { (Veeruraj et al, 2013) }\end{array}$ \\
\hline Amide A & 3421.72 & $3400-3440$ & N-H str \\
\hline Amide B & 2926.01 & $2922-2924$ & asymmetrical of $\mathrm{CH}_{2}$ str \\
\hline Amide I & 1651.07 & $1600-1700$ & $\mathrm{C}=\mathrm{O}$ str \\
\hline Amide II & 1541.12 & $1480-1575$ & N-H bending/ C-N str \\
\hline Amide III & 1240.23 & $1229-1301$ & $\begin{array}{c}\text { C-N stretching with } \\
\text { combination with N-H def }\end{array}$ \\
\hline
\end{tabular}

\section{Toxicity Assay}

The BSLT method is a simple toxicity test on bioactive compounds based on the cytotoxic ability of the test compounds to kill zoological organisms, Artemia salina Leach. The results of the BSLT method are shown in the form of $\mathrm{LC}_{50}$ in $\mu \mathrm{g} / \mathrm{ml}$, which is the ability of the compound which causes $50 \%$ mortality of test animals.

The $\mathrm{LC}_{50}$ value for fish bone collagen was $8.760 \mu \mathrm{g} / \mathrm{mL}$. Based on Clarkson's toxicity criterion for the toxicity assessment, extracts with LC50 of $0-100 \mu \mathrm{g} / \mathrm{ml}$ are highly toxic (Hamidi, 2014) Bone collagen has high toxicity to be used as a natural anticancer agent.

\section{CONCLUSION}

Collagen can be extracted from Lutjanus sp. bone by using hidroextraction method. The yield of collagen was $4.535 \%$ with protein concentration was $8,815 \mathrm{mg} / \mathrm{mL}$. Identified collagen can be known from spectrum of amide A, B, I, II, and III. The toxicity test shown in $\mathrm{LC}_{50}$ values of $8.760 \mu \mathrm{g} / \mathrm{mL}$.

\section{REFERENCES}

Baehaki, A., Nopianti, R., Anggraeni, S., 2015, Antioxidant Activity of Skin and Bone Collagen
Hydrolyzed from Striped Catfish (Pangasius pangasius) with papain enzyme. J Chem Pharm Res, 7(11): 131-135.

Baehaki, A., Lestari, S.D., Desliani, I., 2016, Collagen Hydrolysis from Skin and Bone of Pangasius Catfish Prepared by Bromelain Enzyme and Antioxidant Activity of Hydrolysate. Der Pharma Chemica, 8(4): 155-158.

Duarte, A. S., Correia A., Esteves, A. C., 2016, Bacterial collagenases - A review. Crit Rev Microbiol, 42(1): 106-126.

Gelse, K. P. and Aigner T., 2003, Collagens-Structure, Function, and Biosynthesis, Adv Drug Deliv Rev, 55: 1531-1546.

Hamidi, M. R., Jovanova, B., Panovska, T. K., Toxicological Evaluation of The Plant Products Using Brine Shrimp (Artemia salina L.) Model, 2014, Maced pharm bull, 60 (1): 9-18.

Han, S. H., Uzawa, Y., Moriyama, T., Kawamura, Y., 2011, Effect of Collagen and Collagen Peptides from Bluefin Tuna Abdominal Skin on Cancer Cells. Health, 3(3): 129-134.

Kittiphattanabawon, P., Benjakul, B., Visessanguan, W., Nagai, T., Tanaka, M., 2005, Characterisation of acid-soluble collagen from skin and bone of bigeye snapper (Priacanthus 
tayenus). Food Chem, 89: 363372.

Lee, C. H., Singla, A., Lee, Y., 2001, Review Biomedical Applications of Collagen, Int J Pharm, 221: 122.

Liu, H., Huang, K., 2016, Structural Characteristics of Extracted Collagen from Tilapia (Oreochromis mossambicus) Bone: Effects of Ethylenediaminetetraacetic Acid Solution and Hydrochloric Acid Treatment. Int J F Prop, 19(1): 63-75.

Muthukumar, T., Sreekumar, G., Sastry, T. P., Chamundeeswari, M., 2018, Collagen as A Potential Biomaterial in Biomedical Applications, Rev Adv Mater Sci, 53: 29-39.

Nagai, T., Suzuki, N., 2000, Isolation of Collagen from Fish Waste Material -Skin, Bone and Fins. Food Chem, 68: 277-281.

Schmidt, M. M., Dornelles, R. C. P., Mello, R.O., et al, 2016, Collagen Extraction Process. IFRJ, 23(3): 913-922.

Shoulders, M. D., Raines, R. T., 2009, Collagen Structure and Stability. Annu Rev Biochem, 78: 929-958.

Silva, T. F., Penna, A. L. B., 2012, Colágeno: Características Químicas E Propriedades Funcionais. Rev Inst Adolfo Lutz, 71(3): 530-539.

Silva, M. H., Silva, J. M., Marques, A. L. P., Domingues, A., Bayon, Y., Reis, R. L., 2014, (Review) Marine Origin Collagens and Its Potential Applications. Mar Drugs, 12: 5881-5901

Silvipriya, K. S., Kumar, K. K., Bhat, A. R., Kumar, D., John, A., Lakshmanan, P., 2015, Collagen: Animal Sources and Biomedical
Application. J Appl Pharm Sci, 5(03): 123-127.

Tziveleka, L. A., Ioannou, E., Tsiourvas, D., Berillis, P., Foufa, E., Roussis, V., 2017, Collagen from The Marine Sponges Axinella cannabina and Suberites carnosus: Isolation and Morphological, Biochemical, and Biophysical Characterization, Mar Drugs, 15(152): 1-17.

Veeruraj, A., Arumugam, M., Balasubramanian, T., 2013, Isolation and Characterization of Thermostable Collagen from The Marine Eel-Fish (Evenchelys macrura), Process Biochem, 48: 1592-1602. 